\title{
The Evaluation of Inhibition Effects of Antibiotics on the Sheep Stomach Carbonic Anhydrase I and II Isozymes
}

\section{Namık KILINÇ ${ }^{1}$, Şükrü BEYDEMIR²}

ABSTRACT: Carbonic anhydrases are vital class of enzymes that participate in so many essential physiological events in the organism and associated with many diseases. Inhibitors of carbonic anhydrase enzymes are used in pharmacological applications in many areas such as antiobesity, antiglaucoma, anticancer agents and anticonvulsants. So, this study focuses on the characterization of CA-I and CA-II isoenzymes purified from sheep stomach and investigating the inhibition effects of antibiotics on these enzymes. The findings show that the antibiotics studied strongly inhibit CA-I and CA-II isozymes. In our presented study, using Sepharose 4B-L-Tyrosine sulfanilamide affinity gel chromatography, carbonic anhydrase I and carbonic anhydrase II isoenzymes were purified from sheep stomach with a yield of $51.9 \%, 78 \%$, respectively and specific activity of CA I and CA II are 4864.8 $\mathrm{EU} / \mathrm{mg}$ and $5652.02 \mathrm{EU} / \mathrm{mg}$, respectively. The overall purifications from sheep stomach CA I and CA II were approximately 529.4 and 615.2 fold respectively. To check the purify of the enzymes, it was conducted an electrophoretic method so-called Sodium Dodecyl Sulphate-Polyacrylamide Gel Electrophoresis (SDS-PAGE) and single bands were detected for both enzymes. Additionally, the effects of antibiotics on sheep stomach CA I and CA II isozymes activities, using both hydratase and esterase activity methods, were researched. $\mathrm{IC}_{50}$ values of enrofloxacin, tylosin and ampicillin antibiotics that inhibit CA I enzyme with hydratase activity were found as $1.41,0.033$ and $1.56 \mathrm{mM}$, respectively. $\mathrm{IC}_{50}$ values for CA II enzyme with hydratase activity of the same antibiotics were found as $2.47,0.039$ and $1.63 \mathrm{mM}$, respectively. Kanamycin and amikacin antibiotics inhibited both CA I and CA II enzymes with esterase activity. IC $_{50}$ values for CA I and CA II enzymes with esterase activity of kanamycin antibiotic were determined as 0.0488 and $0.118 \mathrm{mM}$, respectively. $\mathrm{IC}_{50}$ values of amikacin for CA I and CA II enzymes with esterase activity were determined as 0.0163 and $0.036 \mathrm{mM}$, respectively.

Keywords: Sheep stomach, carbonic anhydrases, antibiotics, enzyme inhibition

\footnotetext{
${ }^{1}$ Namık KILINÇ (Orcid ID: 0000-0002-9102-1370), Department of Medical Services and Techniques, Vocational School of Health Service, Igdir University, Igdir, Turkey

${ }^{2}$ Şükrü BEYDEMIR (Orcid ID: 0000-0003-3667-6902), Department of Biochemistry, Faculty of Pharmacy, Anadolu University, Eskişehir, Turkey

*Sorumlu Yazar/Corresponding Author: Şükrü BEYDEMIR, e-mail: sukrubeydemir@anadolu.edu.tr

Bu çalışma Namık KILINÇ’ın Yüksek Lisans tezinden üretilmiştir.

Makale 27.06.2011- 02.07.2011 tarihleri arasında Erzurum'da düzenlenen “25. Uluslararası katılımlı Ulusal Kimya Kongresi'nde" poster olarak sunulmuştur. 


\section{INTRODUCTION}

The carbonic anhydrase (CA, EC 4.2.1.1), in the class of metalloenzymes, is an enzyme that forms bicarbonate, and proton by hydration of carbon dioxide. This reaction, which can also take place without any catalyst, is quite rapid in the presence of the $\mathrm{CA}$ enzymes. $\mathrm{CO}_{2}$, bicarbonate and protons are molecules/ions that are essential to all living things in many important physiological processes (Supuran, 2008). While biological membranes are highly resistant to diffusion of hydrogen ion and bicarbonate, $\mathrm{CO}_{2}$ formed within the cell can easily pass through the membrane. This facilitated diffusion is eliminated through the carbonic anhydrase's catalytic activity (Geers and Gros, 2000).

The presence of carbonic anhydrase in different cell compartments or tissues of different species of livings (Bacteria, Archaea, and Eukarya) suggests that CAs have independently evolved at least five times with five genetically different families of enzymes known to date (Supuran, 2010). This enzyme family is divided into four subclasses according to their cellular localization: cytosolic (CA I, II, III, VII), membrane-associated (CAs IV, IX, XII, XIV), mitochondrial (CA V), and secretory (CA VI) (Potter and Harris, 2003). These enzymes are vital players in so many physiological events such as bone resorption, signal transduction, respiration, kidney, and male reproductive acidification, gluconeogenesis, and gastric acid formation (Sly and Hu, 1995). Because of all these physiological processes they involved, carbonic anhydrases have become interesting targets for inhibitor or activator synthesis. However, synthesized CA inhibitors are still not at the desired level. They show many undesirable side effects such as depression, metallic taste, metabolic acidosis, fatigue, transient myopia, weakness, gastrointestinal irritation, decreased libido, and kidney stones (Dodgson, 1987; Spencer et al., 1988; Dodgson and Cherian, 1989; Chegwidden and Spencer, 1996; Caglayan et al., 2019).

Inhibitors of carbonic anhydrase enzymes are used in pharmacological applications in many areas such as antiobesity, antiglaucoma, anticancer agents and anticonvulsants. However, the use of these inhibitors in the design of antifungal and antibacterial agents is also a novel approach (Supuran, 2012; Liu et al., 2012; Sahin et al., 2012). The synthesis of CA enzyme inhibitors has become increasingly interesting. Sulfonamides and isoester derivatives of sulfonamides, that bind to the enzyme's active site, are the primary class of carbonic anhydrase inhibitors (Supuran, 2012). Recently, several CA inhibitors (CAIs) have been designated which have a different mechanism of action than sulfonamides. Polyamines, phenols, sulfocoumarins, and certain carboxylates have been reported to bind to the zinc coordinated water molecule in the active site of the enzyme (Ozensoy et al., 2011; Sahin et al., 2011; Şentürk et al., 2012; Gündoğdu et al., 2019).

Carbonic anhydrase enzymes are associated with cancer as well as many other diseases. CA enzymes have been reported to promote tumor growth and express in malignant tumor cells by causing increased intracellular alkalization and increased extracellular acidity (Chiche et al., 2009). In a study conducted on Gastrointestinal Stromal Tumors (GISTs), CA II a quite high activity was detected despite relatively low CA I activity (Parkkila et al., 2010).

Kanamycin and amikacin, which are a subclass of aminoglycosides, are antibiotic that treats infections caused by Gram-positive and Gram-negative bacteria by interfering with protein synthesis (Oertel et al., 2004; Zhanel et al., 2012). Enrofloxacin, which is used in both human and animal medicine, is an antimicrobial agent from the broad antimicrobial spectrum group of fluorinated quinolones and high bactericidal activity (Dimitrova et al., 2007). Tylosin is a macrolide antibiotic that is often used against Gram-positive bacteria and mycoplasmas. Tylosin is used in human medicine, as well as in the treatment of conditions caused by sensitive microorganisms in poultry, cattle, and pigs (Baguer et al., 
2000). Ampicillin is a $\beta$-lactam/ $\beta$-lactamase inhibitor with a wide spectrum of antibacterial activity against Gram-negative, Gram-positive and anaerobic bacteria (Rafailidis et al., 2007).

\section{MATERIALS AND METHOD}

\section{Providing of Sheep Stomach and Preparation of Homogenate}

Sheep stomachs used in the study were obtained fresh from a local slaughterhouse. Sheep stomachs were taken kept in ice and brought to the laboratory. Sheep stomach tissues were chopped in small pieces and washed with $0,9 \% \mathrm{NaCl}$ liquid solution, three times. Then, stomach samples were homogenized in Tris- $\mathrm{HCl} / \mathrm{Na}_{2} \mathrm{SO}_{4}$ buffer ( $\mathrm{pH}=8.7$ ) to be $3 \mathrm{ml} \mathrm{g}^{-1}$, after applying liquid nitrogen. Provided solutions were centrifuged for thirty mins at $15,000 \mathrm{xg}$. The supernatant was taken and ultracentrifuge was performed at $100000 \mathrm{xg}$. The supernatant was used for the analysis (K1lınç et al., 2015).

\section{Application of Sheep Stomach Homogenate to The Affinity Column and Elution of the Enzyme}

The $\mathrm{pH}$ of the homogenate solution provided from sheep's stomach was set to 8.7. Subsequently, the solution was exerted to the affinity column and $500 \mathrm{~mL}$ of Tris-HCl/ $\mathrm{Na}_{2} \mathrm{SO}_{4}(\mathrm{pH}=8.7$ ) buffer solution passed through the column. In this way, the carbonic anhydrase enzymes were attached to the affinity column material and unwanted components were taken away. Then, $25 \mathrm{mM} \mathrm{Na} 2 \mathrm{HPO}_{4} / 1 \mathrm{M} \mathrm{NaCl}$ $(\mathrm{pH}=6.3$ ) buffer solution was exerted to the affinity column and CA-I enzyme was taken as an elution. Subsequently, $0.1 \mathrm{M} \mathrm{NaCH}_{3} \mathrm{COO}_{3} 3 \mathrm{H}_{2} \mathrm{O} / 0.5 \mathrm{M} \mathrm{NaClO}_{4}(\mathrm{pH}=5.6)$ solution was exerted to the affinity column and the CA-II enzyme was taken as an elution. The column's flow rate was set to $20 \mathrm{~mL}$ hour $^{-1}$ thorough a peristaltic pump. Using a fraction collector, the elutions were put into tubes in $1.5 \mathrm{~mL}$ and their absorbance at $280 \mathrm{~nm}$ was checked (Alim et al., 2015).

\section{Dialysis}

Tubes obtained from the affinity column and showing high absorbance at $280 \mathrm{~nm}$ were combined separately and put into dialysis bags and dialyzed with dialysis buffer (containing $1 \mathrm{mM} \beta$ mercaptoethanol, $0.05 \mathrm{M}$ Tris- $\mathrm{SO}_{4} \mathrm{pH}=7.4$ ) for two hours. Dialyzation was performed in a cold environment (Kilinc et al., 2014).

\section{Control of Enzyme Purity by Sodium Dodecylsulfate-Polyacrylamide Gel Electrophoresis (SDS- PAGE)}

After applying purification procedures, the purity checks of sheep stomach CA enzymes obtained with the Sepharose 4B affinity column were conducted by the 3-8\% batch SDS-PAGE method (Laemmli, 1970).

\section{Specification of the Enzyme's Molecular Weight by Performing SDS-PAGE}

As specified by Laemmli (1970)'s molecular weight determination method, the molecular mass determination was made as follows; Bovine erythrocyte carbonic anhydrase $29 \mathrm{kDa}$, rabbit phosphorylase B $97 \mathrm{kDa}$, bovine serum albumin $66 \mathrm{kDa}$, ovalbumin $45 \mathrm{kDa}$ proteins were used as standard protein. After the electrophoresis procedures for each tissue, standard proteins' Rf values were computed and $\log$ MW-Rf standard graphics were drawn. Then, Rf values of CA enzymes obtained from stomach tissue were calculated separately and replaced by the standard chart, and the log-MW of CA-I and CA-II isoenzymes was determined. The molecular masses of the samples were determined by taking antilogarithm of these values (Beydemir et al., 2002).

\section{Activity Determination of Carbonic Anhydrase Enzyme}

Two basic methods are used to assay CA enzyme activity; The first method, so-called $\mathrm{CO}_{2}$ hydratase activity, is the primary and physiologic activity measurement method of CAs, and the second 
method, called esterase activity, is an in vitro method based on the spectrophotometric measurement principle.

\section{$\mathrm{CO}_{2}$-hydratase activity}

This method is the activity measurement method used by Wilbur-Anderson, modified by Rickli et al. (Wilbur and Anderson, 1948). The $\mathrm{pH}$ changing results from the $\mathrm{H}^{+}$ion released as a result of the $\mathrm{CO}_{2}$ hydration is determined via the bromine-thymol blue indicator's color changing and is based on the measurement of the slipped by time.

\section{Esterase activity}

The fundamental of the method is briefly as follows; The carbonic anhydrase enzyme hydrolyzes p-nitrophenylacetate used as a substrate to p-nitrophenolate or p-nitrophenol, which absorbs at $348 \mathrm{~nm}$. At $348 \mathrm{~nm}$, p-nitrophenolate and p-nitrophenol both show the same absorbance(Armstrong et al. 1966; Verpoorte et al., 1967).

\section{Quantitative Protein Determination by Bradford Method}

The amount of quantitative protein in the prepared from sheep stomach homogenate and enzyme solutions purified by Sepharose 4B-L-tyrosine sulfanilamide affinity chromatography samples were determined by this method. In this method, bovine serum albumin is used as a standard protein and based on discovering the amount of protein using a standard graphic based on the absorbance at $595 \mathrm{~nm}$ (Bradford, 1976).

\section{Kinetic Studies on CA I and CA II Isozymes Purified from Sheep Stomach Tissue}

\section{Optimum temperature}

Temperature-Activity (EU mL $\left.{ }^{-1}\right)$ graph was drawn by spectrophotometrically measuring esterase activity using digital water bath to determine the optimum temperature value of CA enzymes purified from sheep stomach (Kaya et al., 2013).

\section{$K_{M}$ and $V_{\text {max }}$ values for $p$-nitrophenylacetate substrate}

To determine the $\mathrm{K}_{\mathrm{M}}$ and $\mathrm{V}_{\max }$ values of CA I and CA II isozymes purified from sheep stomach for p-nitrophenilacetate substrate, their activities were computed under optimum conditions and Lineweaver-Burk plot was drawn and $\mathrm{K}_{\mathrm{M}}$ and $\mathrm{V}_{\max }$ values were calculated from this graph (Lehninger, 2005).

\section{In Vitro inhibition studies}

Antibiotics showing inhibitory effect were determined through assaying the catalytic activity of CAs with several inhibitor concentrations. Those with high inhibition effect from these antibiotics were plotted as $\%$ Activity- [I], IC 50 values were calculated from the equation of the curve. In order to determine the $\mathrm{K}_{\mathrm{i}}$ values of antibiotics for which $\mathrm{IC}_{50}$ values were calculated, Lineweaver-Burk plots were drawn by performing activity measurements at different concentrations of antibiotics that inhibit sheep stomach CA I and CA II isozymes with five concentrations of a suitable substrate (Kılınç et al., 2018; Alım, 2019).

\section{RESULTS AND DISCUSSION}

Carbonic anhydrase I and II isozymes were purified from sheep stomach by affinity chromatography, $51.9 \%$ and $78 \%$ yield, respectively. The purification fold was determined as 529.4 and 615.2-fold, respectively (Table 1). 
Table 1. Sheep stomach CA I and CA II purification results

\begin{tabular}{lcccccccc}
\hline \multicolumn{1}{c}{$\begin{array}{c}\text { Purification } \\
\text { Steps }\end{array}$} & $\begin{array}{c}\text { Activity } \\
\left(\mathbf{E U} \mathbf{~ m L}^{-\mathbf{1}}\right)\end{array}$ & $\begin{array}{c}\text { Total } \\
\text { Volume } \\
(\mathbf{m L})\end{array}$ & $\begin{array}{c}\text { Total } \\
\text { Activity } \\
(\mathbf{E U})\end{array}$ & $\begin{array}{c}\text { Protein } \\
\left(\mathbf{m g} \mathbf{~ m L}^{-1}\right)\end{array}$ & $\begin{array}{c}\text { Total } \\
\text { Protein } \\
(\mathbf{m g})\end{array}$ & $\begin{array}{c}\text { Specific } \\
\text { Activity } \\
\left(\mathbf{E U} \mathbf{~ m g}^{-1}\right)\end{array}$ & $\begin{array}{c}\text { Yield } \\
(\boldsymbol{\%})\end{array}$ & $\begin{array}{c}\text { Purification } \\
\text { fold }\end{array}$ \\
\hline Homogenate & 65 & 40 & 2600 & 7.07 & 282.8 & 9.19 & 100 & 1 \\
\hline $\begin{array}{l}\text { Sepharose 4B affinity } \\
\text { chromatography CA I }\end{array}$ & 90 & 15 & 1350 & 0.0185 & 0.2775 & 4864.8 & 51.9 & 529.4 \\
\hline $\begin{array}{l}\text { Sepharose 4B affinity } \\
\text { chromatography CA II }\end{array}$ & 290 & 7 & 2030 & 0.0513 & 0.3591 & 5652.02 & 78 & 615.2 \\
\hline
\end{tabular}

The purity control of carbonic anhydrase I and II enzymes purified from sheep stomach was checked by the batch SDS-PAGE method. As a result of the SDS-PAGE method, single bands were detected for both enzymes (Figure 1).

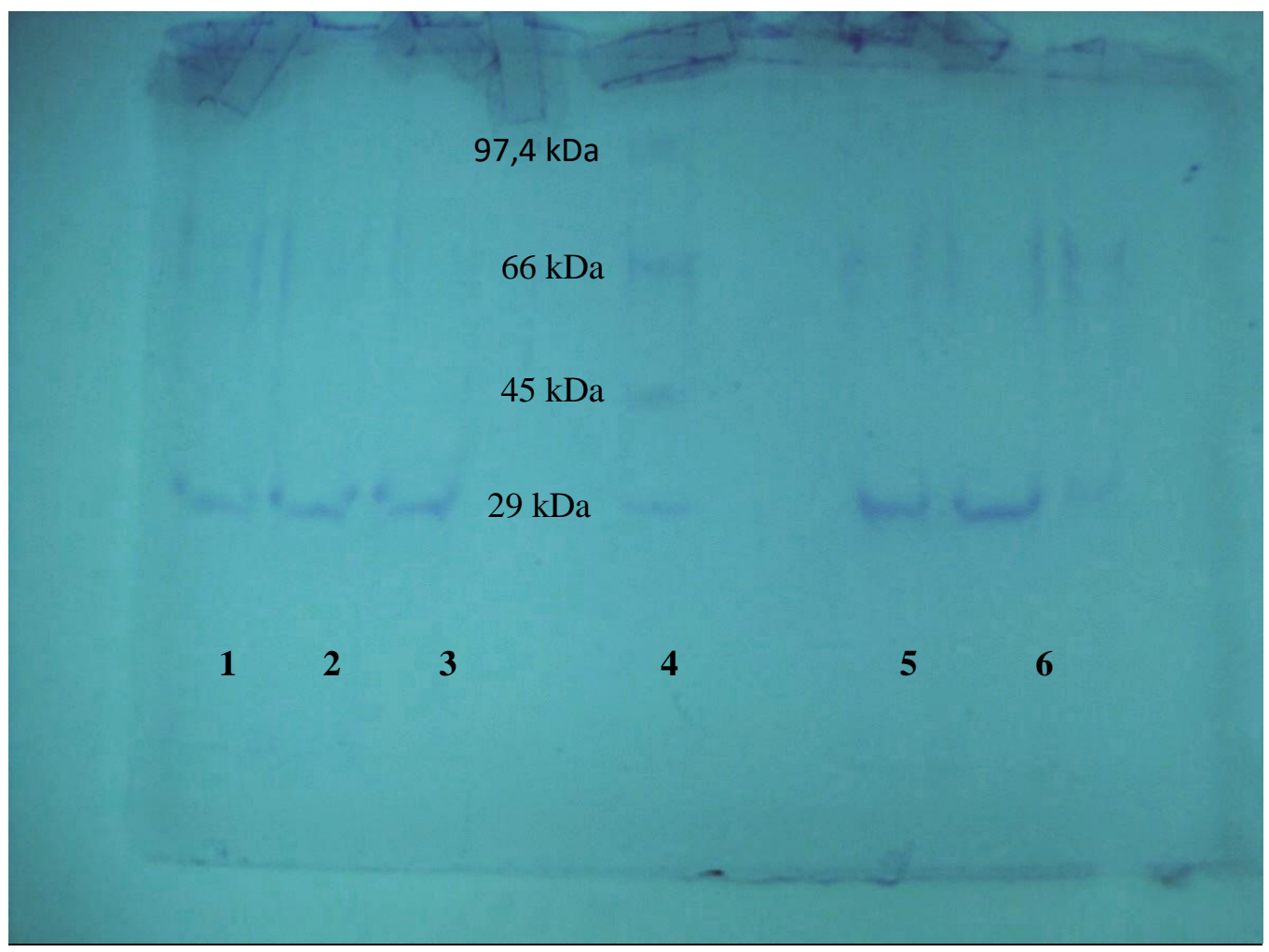

Figure 1: SDS-polyacrylamide gel electrophoresis photograph of sheep stomach carbonic anhydrase I and II isoenzymes purified by affinity chromatography * 4: standard proteins: Phosphorylase ( $97.4 \mathrm{kDa})$, bovine serum albumin (66 kDa), ovalbumin (45 kDa), bovine erythrocyte carbonic anhydrase (29 kDa). (1), (2) and (3) CA I, (5) and (6) CA II enzyme

The molecular weights of enzymes were calculated as $26.7 \mathrm{kDa}$ with the same method. Some kinetic properties of carbonic anhydrase I and II isozymes purified from sheep's stomach were also determined. For this purpose, activity assaying at several temperatures were made for both enzymes using a digital water bath and it was determined that the optimum temperature of both enzymes was $50^{\circ} \mathrm{C}$. In addition, in order to determine the $\mathrm{K}_{\mathrm{M}}$ and $\mathrm{Vmax}$ values for the p-nitrophenylacetate substrate, activity measurements were made at different substrate concentrations. Lineweaver-Burk graphs were drawn and the $\mathrm{K}_{\mathrm{M}}$ value for carbonic anhydrase I was determined as $1.32 \mathrm{mM}$ and the Vmax value was $0.22 \mathrm{EU} \mathrm{mL}^{-1}$. For carbonic anhydrase II, the $\mathrm{K}_{\mathrm{M}}$ value was determined as $1.938 \mathrm{mM}$ and the Vmax value as $0.329 \mathrm{EU} \mathrm{mL}^{-1}$ (Table 2).

Inhibition effects of antibiotics on CA-I and CA-II isoenzymes purified from sheep stomach were also investigated using both esterase and hydratase activity methods, and these antibiotics were found to inhibit sheep stomach CA-I and CA-II enzymes quite well. Inhibition effect results of antibiotics on these enzymes are given in Table 3 as a whole. 
Table 2. Overall results of kinetic studies for sheep stomach CA I and CA II

\begin{tabular}{|c|c|c|}
\hline & CA I & CA II \\
\hline Optimum temperature $\left({ }^{\circ} \mathrm{C}\right)$ & 50 & 50 \\
\hline $\mathbf{K}_{\mathbf{M}}(\mathbf{m M})$ & 1.32 & 1.97 \\
\hline $\mathbf{V}_{\max }\left(\mathbf{E} \mathbf{U} \mathbf{m L}^{-1}\right)$ & 0.22 & 0.33 \\
\hline $\begin{array}{c}\text { Determination of molecular } \\
\text { mass (kDa) } \\
\text { (via SDS-PAGE) }\end{array}$ & 26.7 & 26.7 \\
\hline
\end{tabular}

Table 3. Overall inhibition results of antibiotics that inhibit sheep stomach CA I and CA II isozymes with both esterase and hydratase activity

\begin{tabular}{ccccccccc}
\hline & \multicolumn{4}{c}{ CA I } & \multicolumn{3}{c}{ CA II } \\
\cline { 2 - 9 } Antibiotics & $\begin{array}{c}\text { Hydratase } \\
\text { Activity }\end{array}$ & \multicolumn{2}{c}{ Esterase Activity } & $\begin{array}{c}\text { Hydratase } \\
\text { Activity }\end{array}$ & \multicolumn{2}{c}{ Esterase Activity } \\
\cline { 2 - 10 } & $\mathbf{I C}_{\mathbf{5 0}}(\mathbf{m M})$ & $\begin{array}{c}\mathbf{I C}_{\mathbf{5 0}} \\
(\mathbf{m M})\end{array}$ & $\begin{array}{c}\text { Average } \\
\mathbf{K}_{\mathbf{i}}(\mathbf{m M})\end{array}$ & $\begin{array}{c}\text { Inhibition } \\
\text { type }\end{array}$ & $\begin{array}{c}\mathbf{I C}_{\mathbf{5 0}} \\
(\mathbf{m M})\end{array}$ & $\begin{array}{c}\mathbf{I C}_{\mathbf{5 0}} \\
(\mathbf{m M})\end{array}$ & $\begin{array}{c}\text { Average } \\
\mathbf{K}_{\mathbf{i}}(\mathbf{m M})\end{array}$ & $\begin{array}{c}\text { Inhibition } \\
\text { type }\end{array}$ \\
\hline Kanamycin & - & 0.0488 & $0.147 \pm 0.061$ & Uncompetitive & - & 0.118 & $0.042 \pm 0.0118$ & Uncompetitive \\
Amikacin & - & 0.0163 & $0.042 \pm 0.015$ & Noncompetitive & - & 0.036 & $0.033 \pm 0.0078$ & Noncompetitive \\
Enrofloxacin & 1.410 & 1.32 & $3.850 \pm 1.982$ & Noncompetitive & 2.470 & - & - & - \\
Tylosin & 0.033 & - & - & - & 0.039 & - & - & - \\
Ampicillin & 1.560 & - & - & - & 1.630 & - & - & - \\
\hline
\end{tabular}
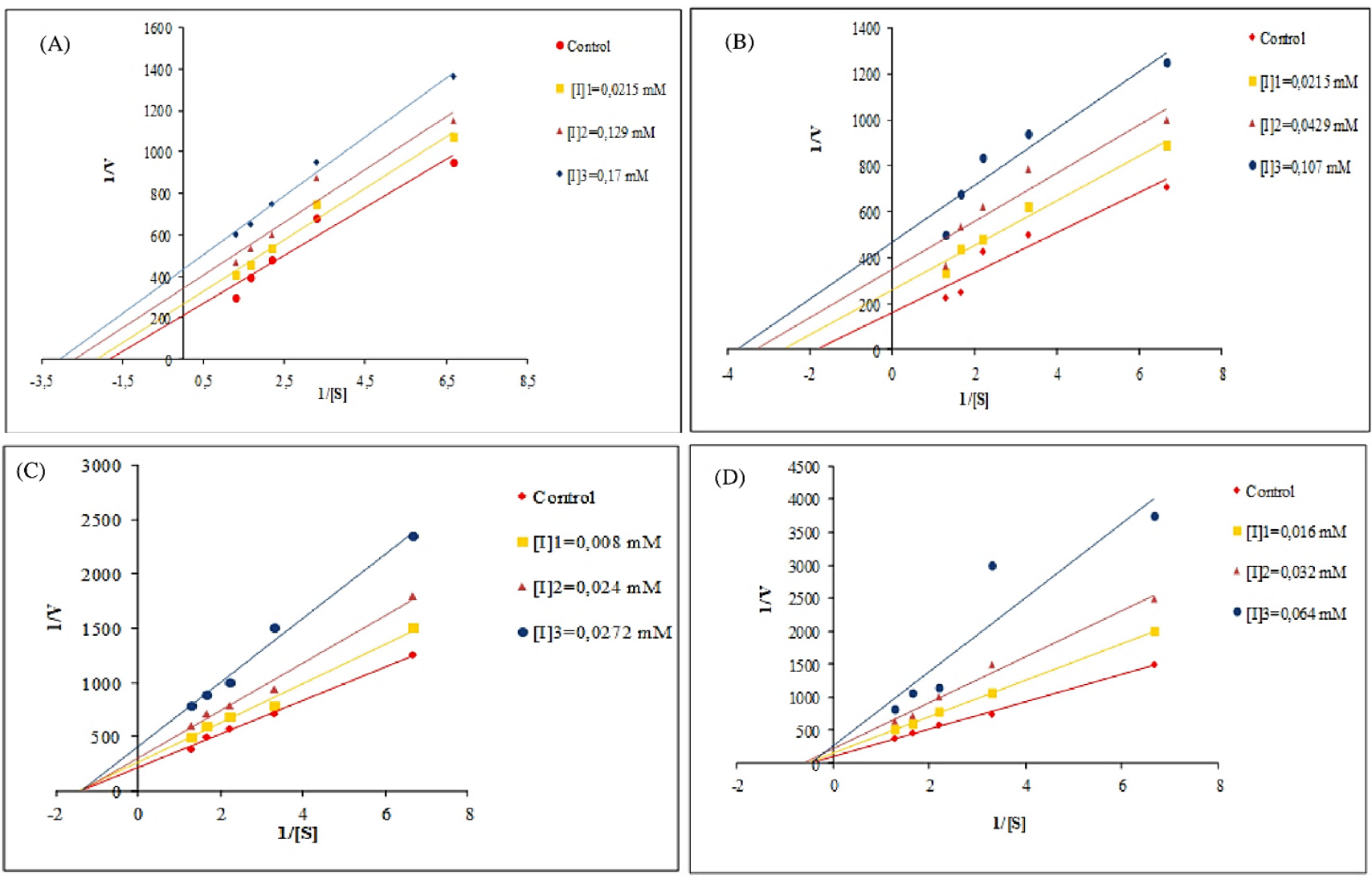

Figure 2. $\mathrm{K}_{\mathrm{i}}$ graphs of kanamycin and amikacin that inhibit sheep stomach CA I and CA II isozymes by esterase activity*(A) and (B), $\mathrm{K}_{\mathrm{i}}$ graphs of kanamycin on CA I and CA II, respectively. (C) and (D), $\mathrm{K}_{\mathrm{i}}$ graphs of amikacin on CA I and CA II, respectively

The most common CA inhibitors are sulfonamides that have been in clinical use for more than 50 years as systemically effective antiglaucoma drugs and diuretics (Supuran et al., 2003). Besides, in recent years, it has been revealed that sulfonamide/sulfamate CAIs have potential as an antiobesity, 
anticonvulsant, pain reliever, anti-infective, and anticancer drugs (Supuran, 2008). In recent years, it has been reported that besides sulfonamides, there are new classes of CA inhibitors that are highly effective on CA enzymes such as polyamines, phenols, sulfocoumarins, and some carboxylates (Şentürk et al., 2012; Ozensoy et al., 2011; Sahin et al., 2011). It is clear from the above information that the inhibition of carbonic anhydrase, which is associated with many diseases, with different groups of chemical molecules, is becoming an increasingly important approach. Therefore, in our research, CA I and CA II isozymes from sheep stomach were purified, some characteristics were determined and the inhibition effects, using both hydratase and esterase activity method, of some antibiotics on these enzymes were investigated. As a result of the inhibition studies conducted, the antibiotics studied have been shown to inhibit both CA I and CA II isoenzymes quite well. In the inhibition study by measuring hydratase activity, tylosin antibiotic showed the best inhibition effect with $0.033 \mathrm{mM} \mathrm{IC}_{50}$ value on CA I enzyme. $\mathrm{IC}_{50}$ values of other antibiotics ampicillin and enrofloxacin are with $1.41 \mathrm{mM}$ and $1.56 \mathrm{mM}$, respectively. The $\mathrm{IC}_{50}$ values of amikacin, Kanamycin, and enrofloxacin, which are inhibitory effects with esterase activity on CA I isoenzyme, were determined as $0.016 \mathrm{mM}, 0.048 \mathrm{mM}$, and $1.32 \mathrm{mM}$, respectively. In the inhibition study by measuring hydratase activity, tylosin antibiotic showed the best inhibition effect with $0.0387 \mathrm{mM} \mathrm{IC}$ I0 $_{50}$ value on the CA II enzyme. IC $_{50}$ values of other antibiotics ampicillin and enrofloxacin are $1.63 \mathrm{mM}$ and $2.47 \mathrm{mM}$, respectively. The $\mathrm{IC}_{50}$ values of amikacin and kanamycin, which are inhibitory effects with esterase activity on CA II isoenzyme, were determined as $0.036 \mathrm{mM}$ and $0.12 \mathrm{mM}$, respectively. It is clear from the results that amikacin and kanamycin antibiotics did not show hydratase activity on both the CA I and CA II isoenzyme. While the enrofloxacin antibiotic showed both esterase and hydratase activity for CA I, it only showed hydratase activity for CA II. It was detected that there is no significant difference between the hydratase and esterase $\mathrm{IC}_{50}$ values of enrofloxacin. The Ki values of the amikacin antibiotic for CA I and CA II are $0.0421 \mathrm{mM}$ and $0.033 \mathrm{mM}$, respectively. The inhibition type for both enzymes is non-competitive. Kanamycin, another antibiotic has CA I and CA II esterase activity, $\mathrm{K}_{\mathrm{i}}$ values of $0.048 \mathrm{mM}$ and $0.12 \mathrm{mM}$, respectively. For both enzymes, it's inhibition type is un-competitive. The Ki value of enrofloxacin, which shows esterase activity only on CA I, is $3.85 \mathrm{mM}$ and the inhibition type is non-competitive.

\section{CONCLUSION}

In conclusion, enzymes CA I and CA II isozymes were purified from sheep stomach, some characteristics were indicated and the inhibition effects of some of the common medically used antibiotics on these enzymes were investigated. The results showed that all the antibiotics studied showed a significant inhibition effect on CA I and CA II isozymes. In particular, amikacin and kanamycin antibiotics, which have an inhibition effect on both enzymes at the micromolar level, have been shown to be good carbonic anhydrase enzyme inhibitors. Considering that carbonic anhydrase inhibitors currently used as medicines show many side effects such as depression, metallic taste, metabolic acidosis, fatigue, transient myopia, weakness, gastrointestinal irritation, decreased libido, and kidney stones, it will be concluded how valuable and important the results are.

\section{REFERENCES}

Alım Z, 2019. Inhibition Effect of Eosin Y on Carbonic Anhydrase (CA) I and II Isoenzymes Purified from Human Erythrocytes. Iğdır Üniversitesi Fen Bilimleri Enstitüsü Dergisi, 10(1): 338-344.

Alım Z, Kılınç N, İşgör MM, Şengül B, Beydemir Ş, 2015. Some Anti-Inflammatory Agents Inhibit Esterase Activities of Human Carbonic Anhydrase Isoforms I and II: An In Vitro Study. Chemical Biology \& Drug Design, 86(4): 857-863. Armstrong JM, Myers DV, Verpoorte JA, Edsall JT, 1966. Purification and Properties of Human Erythrocyte Carbonic Anhydrases. Journal of biological chemistry, 241(21): 5137-5149. 
Baguer AJ, Jensen J, Krogh PH, 2000. Effects of the Antibiotics Oxytetracycline and Tylosin on Soil Fauna. Chemosphere, 40(7): 751-757.

Beydemir Ş, Çiftçi M, Küfrevioğlu Öİ, 2002. Purification and Characterization of Glucose 6-Phosphate Dehydrogenase from Sheep Erythrocytes and Inhibitory Effects of Some Antibiotics on Enzyme Activity. Journal of Enzyme Inhibition and Medicinal Chemistry, 17(4): 271-277.

Bradford MM, 1976. A Rapid and Sensitive Method for the Quantitation of Microgram Quantities of Protein Utilizing the Principle of Protein-Dye Binding. Analytical Biochemistry, 72(1-2): 248-254.

Caglayan C, Demir Y, Kucukler S, Taslimi P, Kandemir FM, Gulçin İ, 2019. The effects of hesperidin on sodium arseniteinduced different organ toxicity in rats on metabolic enzymes as antidiabetic and anticholinergics potentials: A biochemical approach. Journal of food biochemistry, 43(2), e12720

Chegwidden WR, Spencer IM, 1996. Carbonic Anhydrase Provides Bicarbonate for De Novo Lipogenesis in the Locust. Comparative Biochemistry and Physiology Part B: Biochemistry and Molecular Biology, 115(2): 247-254.

Chiche J, Ilc K, Laferrière J, Trottier E, Dayan F, Mazure NM, Brahimi-Horn MC, Pouysségur J, 2009. Hypoxia-Inducible Carbonic Anhydrase IX and XII Promote Tumor Cell Growth by Counteracting Acidosis Through the Regulation of the Intracellular $\mathrm{pH}$. Cancer Research, 69(1): 358-368.

Dimitrova DJ, Lashev LD, Yanev SG, Pandova B, 2007. Pharmacokinetics of Enrofloxacin in Turkeys. Research in Veterinary Science, 82(3): 392-397.

Dodgson SJ, 1987. Inhibition of Mitochondrial Carbonic Anhydrase and Ureagenesis: A Discrepancy Examined. Journal of Applied Physiology, 63(5): 2134-2141.

Dodgson SJ, Cherian K, 1989. Mitochondrial Carbonic Anhydrase is Involved in Rat Renal Glucose Synthesis. American Journal of Physiology-Endocrinology and Metabolism, 257(6): 791-796.

Geers C, Gros G, 2000. Carbon Dioxide Transport and Carbonic Anhydrase in Blood and Muscle. Physiological Reviews, 80(2): 681-715.

Gündoğdu S, Türkeş C, Arslan M, Demir Y, Beydemir Ş, 2019. New Isoindole-1, 3-dione Substituted Sulfonamides as Potent Inhibitors of Carbonic Anhydrase and Acetylcholinesterase: Design, Synthesis, and Biological Evaluation. Chemistry Select, 4(45): 13347-13355.

Kaya ED, Söyüt H, Beydemir Ş, 2013. Carbonic Anhydrase Activity from the Gilthead Sea Bream (Sparus Aurata) Liver: The Toxicological Effects of Heavy Metals. Environmental Toxicology and Pharmacology, 36(2): 514-521.

Kılınç N, Alım Z, İşgör MM, Beydemir Ş, 2014. The Impacts of Some Metals on the Activity of Corb Gill Umbrina Cirrosa Carbonic Anhydrase. Hacettepe Journal of Biology \& Chemistry, 42 (4): 499-504.

Kılınç N, İşgör MM, Şengül B, Beydemir Ş, 2015. Influence of Pesticide Exposure on Carbonic Anhydrase II from Sheep Stomach. Toxicology and Industrial Health, 31(9): 823-830.

Kılınç N, Alım Z, Şengül B, İşgör MM, Beydemir Ş, 2018. Evaluation of Inhibition Effects of Some Cardiovascular Therapeutics on Human Erythrocyte Carbonic Anhydrase Isoenzymes. Bitlis Eren Üniversitesi Fen Bilimleri Dergisi, 7(1): 90-97.

Laemlli DK, 1970. Cleavege of Structural Ptoteins During in Assembly of The head of Bacteriophage. Nature, 227-680.

Liu F, Martin-Mingot A, Lecornué F, Jouannetaud MP, Maresca A, Thibaudeau S, Supuran CT, 2012. Carbonic Anhydrases Inhibitory Effects of New Benzenesulfonamides Synthesized by Using Superacid Chemistry. Journal of Enzyme Inhibition and Medicinal Chemistry, 27(6): 886-891.

Oertel R, Neumeister V, Kirch W, 2004. Hydrophilic Interaction Chromatography Combined with Tandem-Mass Spectrometry to Determine Six Aminoglycosides in Serum. Journal of Chromatography A, 1058(1-2), 197-201.

Özensoy Ö, Arslan M, Supuran CT, 2011. Carbonic Anhydrase Inhibitors: Purification and Inhibition Studies of Pigeon (Columba Livia Var. Domestica) Red Blood Cell Carbonic Anhydrase with Sulfonamides. Journal of Enzyme Inhibition and Medicinal Chemistry, 26(5): 749-753.

Parkkila S, Lasota J, Fletcher JA, Ou WB, Kivelä AJ, Nuorva K, Parkkila AK, Ollikainen J, Sly WS, Waheed A, Pastorekova S, Pastorek J, Isola J, Miettinen M, 2010. Carbonic Anhydrase II. A Novel Biomarker for Gastrointestinal Stromal Tumors. Modern Pathology, 23(5): 743.

Potter CPS, Harris AL, 2003. Diagnostic, Prognostic and Therapeutic Implications of Carbonic Anhydrases in Cancer. British Journal of Cancer, 89(1): 2.

Rafailidis PI, Ioannidou EN, Falagas ME, 2007. Ampicillin/Sulbactam. Drugs, 67(13): 1829-1849.

Sahin H, Aliyazicioglu R, Yildiz O, Kolayli S, Innocenti A, Supuran CT, 2011. Honey, Polen, and Propolis Extracts Show Potent Inhibitory Activity Against the Zinc Metalloenzyme Carbonic Anhydrase. Journal of Enzyme Inhibition and Medicinal Chemistry, 26(3): 440-444. 
Sahin H, Can Z, Yildiz O, Kolayli S, Innocenti A, Scozzafava G, Supuran CT, 2012. Inhibition of Carbonic Anhydrase Isozymes I and II with Natural Products Extracted from Plants, Mushrooms and Honey. Journal Of Enzyme Inhibition and Medicinal Chemistry, 27(3): 395-402.

Sly WS, Hu PY, 1995. Human Carbonic Anhydrases and Carbonic Anhydrase Deficiencies. Annual Review of Biochemistry, 64(1): 375-401.

Spencer IM, Hargreaves I, Chegwidden WR, 1988. Effect of the Carbonic Anhydrase Inhibitor Acetazolamide on Lipid Synthesis in the Locust. Biochemical Society Transactions, 16: 973-974.

Supuran CT, 2008. Carbonic Anhydrases: Novel Therapeutic Applications for Inhibitors and Activators. Nature Reviews Drug Discovery, 7(2): 168.

Supuran CT, 2010. Carbonic Anhydrase Inhibitors. Bioorganic and Medicinal Chemistry Letters. 20(12): 3467-3474

Supuran CT, 2012. Structure-Based Drug Discovery of Carbonic Anhydrase Inhibitors. Journal of Enzyme Inhibition and Medicinal Chemistry, 27(6): 759-772.

Supuran CT, Scozzafava A, Casini A, 2003. Carbonic Anhydrase Inhibitors. Medicinal Research Reviews, $23(2)$ : $146-189$.

Şentürk M, Ekinci D, Göksu S, Supuran CT, 2012. Effects of Dopaminergic Compounds on Carbonic Anhydrase Isozymes I, II, and VI. Journal of Enzyme Inhibition and Medicinal Chemistry, 27(3): 365-369.

Verpoorte JA, Mehta S, Edsall JT, 1967. Esterase Activities of Human Carbonic Anhydrases B and C. Journal of Biological Chemistry, 242(18): 4221-4229.

Wilbur KM, Anderson NG, 1948. Electrometric and Colorimetric Determination of Carbonic Anhydrase. Journal of Biological Chemistry, 176(1): 147-154.

Zhanel GG, Lawson CD, Zelenitsky S, Findlay B, Schweizer F, Adam H, Walkty A, Rubinstein E, Gin AS, Hoban DJ, Lynch JP, Karlowsky JA, 2012. Comparison of the Next-Generation Aminoglycoside Plazomicin to Gentamicin, Tobramycin and Amikacin. Expert Review of Anti-Infective Therapy, 10(4), 459-473. 